\title{
A Monograph of the Ixodoidea
}

By GEORgE H. F. NUTTALL, M.D., Ph.D., Sc.D., F.R.S., CECIL WARBURTON, M.A., F.Z.S., W. F. COOPER, B.A., F.Z.S., F.L.S. and L. E. ROBINSON, A.R.C.Sc. (London).

\section{Now ready. PART I. THE ARGASIDAE. With 116 text figures and 3 plates. Royal 8vo. 5s. net.}

This book will deal with the Classification, Structure and Biology of Ticks, the study of the group having occupied the authors for several years. Practically all that has been published on the subject has received adequate consideration.

The book will be issued in about four parts, which will be complete in themselves but are designed to form a volume of about 500 pages when all the parts have been published. Each part will be issued in a stiff paper cover and will include a bibliography printed on one side of thin paper so that the references can be conveniently cut out and gummed on index cards. A complete bibliography, including all the publications cited in each part will conclude the volume.

"For those who are not experts on Ticks, but are made practically acquainted with them from the pathological point of view, a comprehensive monograph or handbook of the group has become an urgent requirement, and this need will now be supplied by the monograph which is now being produced by Messrs Nuttall, Warburton, Cooper and Robinson."-Nature

\section{OXFORD UNIVERSITY PRESS}

\section{Quarterly Journal of Medicine \\ Edited by}

WILLIAM OSLER, J. ROSE BRADFORD, R. HUTCHISON, A. E. GARROD, H. D. ROLLESTON, AND W. HALE WHITE.

8s. 6d. net per number. Annual Subscription, 25s. Vol. I, 1907-8, 35s. net. Vol. II, 1908-9, 35s. net.

The Last Days of Charles II. By R. Crawfurd. With a drawing from the Effigy in Westminster Abbey reproduced in collotype, and four other illustrations. Medium 8vo. 5s. net.

English Medicine in Anglo=Saxon Times: the Fitz-Patrick Lectures for 1903. By J. F. PAYNE. 8vo, with 23 illustrations. 8s. 6d. net.

The Study of Medicine in the British Isles: the Fitz-Patrick Lectures for 1905-6. By Norman Moore. 8vo, with 13 Collotype plates. 108. $6 d$. net.

The Treatment of Disease. By W. OsLer. 1s. net.

An Alabamia Student and other Biographical Essays. By William OsLer. $8 \mathrm{vo}$, with portraits and other illustrations. $78.6 d$. net. 


\section{PAUL ALTMANN,}

47, Luisen-Strasse,

Ecke Schumann-Strasse, BERLIN, N.W., GERMANY,

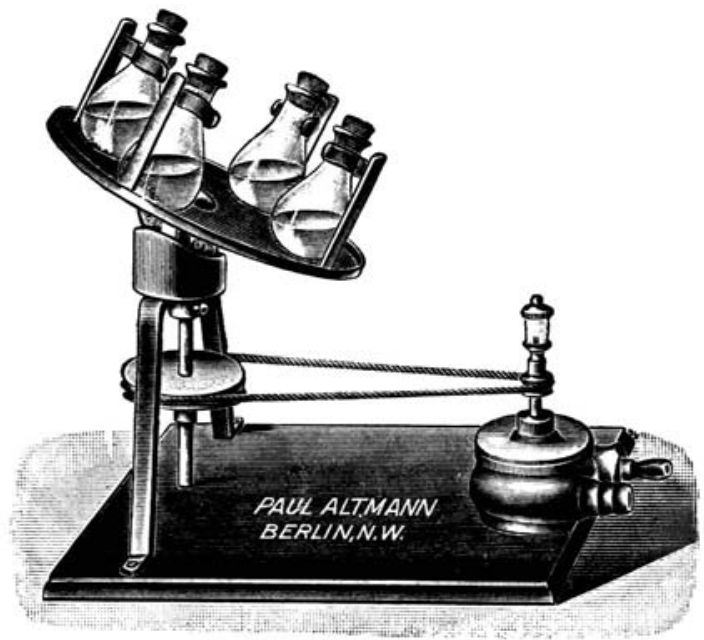

New SHAKING APPARATUS with Water Motor. Mk. 38.0o.
Manufacturer of all kinds of apparatus and appliances for Chemistry, Bacteriology, Microscopy and Hygiene.

All Goods manufactured in our own workshops.

COMPLETE OUTFITS of Bacteriological-Microscopical and Hygieno-Chemical Laboratories.

SPECIALITY :

Disinfecting and Sterilising Apparatus.

Thermostats, adjustable for a Constant Temperature. Autoclaves, Centrifugals.

Apparatus for Clinical

Laboratories, etc., etc.

New apparatus for WATER RESEARCHES.

New apparatus for SERODIAGNOSE.

Full Illustrated Price Lists on Application.

\section{SCIENTIFIC APPARATUS}

\section{JOHN J. GRIFFIN \& SONS, Ltd., KINGSWAY, LONDON, W.C.}

Makers to the Admiralty, War Office, India, Colonial and Foreign Governments.

Every facility for making Apparatus to Original Specifications.

ENQUIRIES SOLICITED.

SOLE DEPÔT FOR KAHLBAUM'S CHEMICALS.

Price-list post-free on application.

\section{THE GEOGRAPHY OF DISEASE}

By FRANK G. CLEMOW, M.D. Edin., D.P.H. Camb.,

British Delegate to the Ottoman Board of Health, Physician to H.M. Embassy at Constantinople

Crown 8vo. Cloth. 12 Maps and Charts. Price 15 s.

“Dr Clemow's writings are well known to all epidemiolouists and his intimate knowledge of the Russian language has enabled him to study the disease and death records of the vast popula. tion of that great European and Asiatic country in a manner which is impossible to most writers. ...In a preface upon the Geography of Disease and the factors which determine it we find dis. cussed in a fascinating fashion the complex nature of the problem."-Lancet 


\title{
IN INFECTIVE DISEASES
}

by

\section{ÉLIE METCHNIKOFF}

Foreign Member of the Royal Society of London, Professor at the Pasteur Institute, Paris

Translated from the French by

FRANCIS G. BINNIE

Of the Pathological Department, University of Cambridge

Royal 8vo. Buckram. Pp. avi 592.

With 45 figures in the text. Price 18s. net.

\begin{abstract}
"The present translation of Prof. Metchnikoff's work has been admirably carried out by Mr Binnie.... We have here the record of five and twenty years of thoughtful speculation tested by laborious experiment, and no more important book on the subject has ever appeared in the English language." -Athenaeum

"It is a scientific monograph of the first order....It would be impertinent to commend his knowledge of the subject, but it is permissible to remark that he here shows himself an expounder of the first order. His marshalling of the multitudinous details is masterly and so lucid that any one who knows the meaning of the words can follow it with ease. And these qualities are enhanced by the true scientific spirit and scrupulous fairness with which arguments are handled."-Times

"The Cambridge University Press has done a real service in publishing tlie Metchnikoff's volume....The book is a work which sums up the labours of a quarter of a century of a life of which fifty years have been devoted to scientific pursuits. What that strenuous life has done for humanity can hardly be over-estimated." -Westminster Gazette
\end{abstract}

CAMBRIDGE UNIVERSITY PRESS, FETTER LANE, LONDON

C. F. Clay, Manager

\section{ROYAL COLLEGE OF PHYSICIANS OF LONDON}

\section{The Weber=Parkes Prize and Medals} PRIZE OF 150 GUINEAS AND TWO SILVER MEDALS

The next award will be made in 1912, and the Adjudicators have selected as the subject of the Essay for that occasion-

The Influence of Mixed and Secondary Infections upon Pulmonary Tuberculosis in Man, and the measures preventive and curative for dealing with them.

"The Essay must be based on original work and observations (experimental or other) of the author, and must include a detailed exposition of the methods employed and their mode of application."

All Essays, together with any preparations made in illustration of them, must be transmitted to the Registrar of the College during the last week of May, 1912, in accordance with the Regulations relating thereto, copies of which will be forwarded from the College on application.

The Award will be made on some day previous to the 18 th October in that year.

Pall-Mall East, S.W.

J. A. ORMEROD, M.D., Registrar. 


\section{CONTENTS}

\section{(All rights reserved)}

Cobbett, L. and Graham-Smith, G. S. An Investigation of the Pathology of "Grouse Disease." (Plates I-V.) . . .

Alexander, D. Moore. An Investigation into the Acid-fast Bacteria found in Human Faeces with Special Reference to their Presence in Cases of Tuberculosis . . . .

KaJiURA, S. and Rosenheim, O. A Contribution to the Etiology of Beri-Beri. (Plate VI.) . . . . . . .

Hewlett, R. Tanner, Villar, Sidney and Revis, Cecil. On the Nature of the Cellular Elements Present in Milk. Part II. Quantitative and Qualitative Results. (One Text figure.). . . . . . . . . . .

Buchan, George F. The Contamination of Ice-cream.

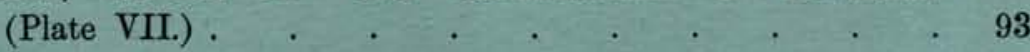

International Hygiene Exhibition Dresden 1911 . ‘ . . 131

Nicolle, CH, Investigations on Typhus Fever . . . . . 135

The Journal of Hygiene is issued quarterly. A volume containing about 500 pages, with plates and figures, is issued annually.

Volumes I, II, and III (1901-3) complete. In Four Parts, paper covers, 15s. net per volume. Bound in buckram, 18s. $6 d$. net per volume.

Volumes IV, V, VI, VII, VIII and IX (1904-9) complete. In Parts, paper covers, 21s. net per volume. Bound in buckram, 25s. net per volume.

Papers for publication may be sent to Prof. Geo. H. F. Nutrall, F.R.S., 3 Cranmer Road, Cambridge, or to the associate Editors. Other communications should be addressed to the University Press, Cambridge.

Papers forwarded to the Editors for publication are understood to be offered to the Journal of Hygiene alone, unless the contrary is stated.

Contributors receive fifty copies of their papers free. Additional copies may be had at cost price: these should be ordered when the final proof is returned.

The subscription price is £1. 18. per volume (post-free), payable in advance; single numbers 7s. net. (Plague Numbers, Vol. VI. no. 4, Vol. VII. nos. 3 and 6, and Vol. VIII. no. 2, Price 6s. net each.) Subscriptions may be sent to any Bookseller, or to Mr C. F. CLAY, MaNAGER, Cambridge University Press, Fetter Lane, London, E.C. 